BYRON RANGIWAI, BENITA SIMATI-KUMAR CHAND, AND ROSIE MATAROA

\title{
The impacts of COVID-19 on the 2020 cohort of the Master of Applied Indigenous Knowledge programme at Te Wānanga o Aotearoa in Māngere
}

COVID-19 is a significant challenge to education and learning (Crawford, et al., 2020; Daniel, 2020; Händel et al., 2020; Naciri et al., 2020; Toquero, 2020; Usak et al., 2020). COVID-19 caused face-to-face learning to become a threat to health (Murphy, 2020) which has meant that learning around the world moved online very rapidly (Alawamleh, 2020; Daniel, 2020; Händel et al., 2020; Sandars et al., 2020) on an untried and unparalleled scale (Burgess \& Sievertsen, 2020). Because of the extraordinary conditions that education is experiencing globally, institutions must document the effects of the COVID-19 on the delivery of education (Toquero, 2020) to ensure that it is as effective as possible (Sahu, 2020). The purpose of this article is to document some of the COVID19 challenges and experiences of the 2020 Master of Applied Indigenous Knowledge cohort.

Byron Rangiwai holds a Bachelor of Arts from the University of Waikato, a Master of Indigenous Studies with First Class Honours from Te Whare Wānanga o Awanuiārangi, a PhD in Māori and Indigenous Development from Auckland University of Technology, and a PhD in Māori, Pacific and Indigenous Studies from the University of Otago.

Benita Simati-Kumar holds a Bachelor of Art and Design with Honours, a Master of Art and Design with First Class Honours, and a PhD in Māori and Indigenous Development from Auckland University of Technology.

Benita and Byron are Lecturers, and Rosie is the Course Coordinator, for the Master of Applied Indigenous Knowledge degree at Te Wānanga o Aotearoa, Māngere, Auckland. 
The Master of Applied Indigenous Knowledge is a twoyear programme that recognises the expertise of Indigenous practitioners in particular fields of knowledge and guides them through the process of writing a 15,00020,000-word exegesis and completing a research-based project that significantly contributes to the development of their Indigenous communities. In Year 1, lecturers guide students through the completion of assessments. However, in Year 2, students are supervised by voluntary experts that they select themselves. In Year 2, students must approach and select a voluntary Indigenous Master Practitioner (IMP). This person must be considered an expert in a particular field that relates closely to the field of knowledge and practice of the student. The IMP supervises the project. Students must also select a voluntary tuakana or supervisor-a person with a doctorate-who supervises the exegesis. The 2020 master's cohort is in their first year.

This paper is based on the experiences of the impacts of COVID-19 on the lives and learning of our 2020 master's cohort. The 36 students in the 2020 master's cohort were provided with a short questionnaire, which featured four questions:

- In what ways has COVID-19 impacted on your life?

- In what ways has COVID-19 impacted on your studies?

- Please describe some of the feelings you have experienced concerning COVID-19 and your studies

- What other thoughts would you like to share?

The responses gathered from students were analysed using the thematic analysis approach developed by Braun et al. (2020) which includes the following processes: 
- Familiarisation

- Generating codes

- Constructing themes

- Revising themes

- Defining themes

- $\quad$ Producing the report.

We read the responses many times, discussed these at length, and became very familiar with the dataset. Codes were generated from the dataset. The process involved attaching concise and clear codes to bits of data so that the data could be arranged around emerging patterns of meaning (Braun et al., 2019). Themes were constructed by grouping similar codes together as 'building blocks' with which to construct themes that draw upon patterns of meaning to tell a story (Braun et al., 2019). We then revised and defined the themes to check that they were appropriate. What follows reports what we found out about how COVID-19 has affected our 2020 master's cohort so far.

From the responses gathered from the 2020 master's cohort, we extrapolated the following themes:

- Work-life balance

- Finances

- Health

- Learning

- Commitment and quality

- Staff

\section{Work-life balance}

COVID-19 is disrupting work-life balance around the world as the line between work, and home life become increasingly blurred (Cobera et al., 2020). As expected, our students experienced considerable shifts in work-life 
balance. Specifically, students talked about increased workload, the struggle to achieve balance concerning additional responsibilities, and job losses.

\section{Increased workload:}

"I feel that my workload is doubling because of COVID-19. I teach online three times a week-it is too much. I am a teacher for my children as well."

"Since COVID, my workload increased due to the alarming needs of our communities and the impact that COVID has had on them."

"The impact has been working longer hours without extra pay."

"My workload became too difficult to manage alone, and I had to take on several contractors and am still struggling to cope."

\section{Balance:}

"It has put a lot of pressure on all aspects of my life, with me trying to balance family, master's study and finance exams coming up mid-September."

"Since COVID-19, my roles have been: mother, wife, teacher to three teenage boys, income earner, budgeter, advisor, navigator, student, business developer, advocate and so on. In my bubble, there are six of us; even doing Zoom sessions from home have been stressful, especially for my boys as I will repeatedly ask them to be quiet."

"In addition to working more hours, I've been juggling my kids' learning across four different levels and trying to manage a household in a strained situation." 


\section{Job losses:}

"My husband lost his job. It was a very traumatic and unfair dismissal. Supporting him through this grief process has been heavy."

"My hubby no longer has work. I am now the only income earner in the household."

"We struggle a lot more now on just one income."

\section{Finances}

Financial vulnerability is one of the many undesirable features of the COVID-19 pandemic that has far-reaching effects globally (Mogaji, 2020). Our students candidly described their financial struggles.

"The cost of living in Auckland is already high, and lockdown sends prices up even further so every little increment or change can knock my whole household out of whack and sometimes that's enough to send it all crashing down".

"My parents are ill, and I look after them. During lockdowns, I am the only carer due to restrictions. I had to quit my job to look after my parents fulltime. I do not have an income, and I do not qualify to be paid as a caregiver because I study fulltime. I survive only because I am borrowing student loan living costs through Studylink."

"My clients pay me incredibly late. I have contractors to pay before I am even being paid myself and it makes it financially difficult but I do it to serve vulnerable people who need help."

"I work in finance, helping families. My finance workload has tripled since COVID-19." 


\section{Health}

Psychological issues such as depression and anxiety are common in a pandemic, and specifically COVID-19, context (Cao et al., 2020; Hiremath et al., 2020; Kapasia et al., 2020; Marelli et al., 2020; Odriozola-González et al., 2020; Sahu, 2020; Tang et al., 2020; Wang et al., 2020). Students spoke openly about feeling sad, depressed, anxious, and stressed about COVID-19 generally and more specifically about the impacts of the virus on their master's studies. One respondent, who tragically lost her son this year, spoke explicitly about grief. Other students talked about not coping or not feeling good enough.

Feelings of anxiety, depression, stress and loneliness "During lockdowns, I have had anxiety and meltdowns, where I have resorted to eating for comfort. As a person with type 2 diabetes, this has not been too good for my hauora."

"The pressure of COVID-19 study caused me to experience anxiety and slump into a semi-depressant mode-I was on auto-pilot."

"It has restricted me from seeing my partner and daughter who are in lockdown in Auckland as I live in Hamilton. Feelings of anxiety and loneliness through separation have emerged."

"COVID-19 has created anxieties in the community because people were pointing the finger at Pasifika people-it is a big issue for our people."

"I suffer from anxiety. So, these uncertain times have brought on my anxiety issues. I have spent the past few months since our last noho, stuck at home due to my health conditions." 
"I have felt nervous and anxious at times, especially with deadlines. I am worried that I can't keep up or up to the required standard."

"My anxiety has had the better of me lately because I am worried about coming to South Auckland for the next noho. I do trust that the Wānanga has all of the safety measures in place to keep us safe while we are at the campus. But, my concern is more around where I would be staying in South Auckland."

"I have experienced a lot of anxiety with COVID-19, even more so with this second wave which originated from South Auckland. As much as I would love for us to be able to have a face-to-face wānanga in September where we don't stay overnight, I am still concerned about going to South Auckland-this makes me very anxious."

"Anxiety is the word I would use to describe my ongoing thoughts of COVID-19. The extra stress it has created for myself as an individual to be 'on my game', be conscientious, practice better hygiene measures, is extra work. I naturally do this, but some people do not, and a lot of fear is created from their ignorance and laziness with regard to hygiene practices."

"Not being able to tangihanga and fulfil cultural obligations has been distressing."

"It has been saddening to not see my mokopuna during lockdowns."

"I can't see my family as I am socially isolated."

"I try to research but struggle to focus because I am stressed, I can't say more than that right now." 
"As a result of COVID-19, I have suffered emotionally. The loneliness and sadness that I have experienced and continue to experience may surface in my writing."

\section{Grief}

"COVID-19 has made me more fearful about going places; even going to our local supermarket is tough for me now. I have high blood pressure, and I fear that I might easily contract the virus. I am still recovering from the very recent and great loss of my son. My grief adds to my feelings of uncertainty and fear about COVID-19."

\section{Other feelings}

I'm struggling mentally."

"I feel like a failure."

"The COVID-19 situation brings back triggered memories of when my kids were critically ill with meningitis a few years ago - they were both in a critical condition. I worry that my family will go through more trauma."

\section{Learning}

One student said: "COVID-19 has delayed my progress in the master's programme; it has, at times, depleted the passion for completing my studies." There is no doubt that COVID-19 has negatively impacted on education around the world (Daniel, 2020; Jacob et al., 2020; Usak et al., 2020). Kapasia et al. (2020) note that some students experience problems relating to depression and anxiety, poor internet connectivity, and less than desirable learning environment in the home. Indeed, when access to the internet is severely restricted or absent, it can limit student success in an online learning environment (Adnan \& Anwar, 2020). Our students talked specifically about a lack of resources and support, not being able to study at home, and needing face-to-face teaching/learning. 


\section{Resources/support}

"The financial impact of my studies has also been problematic as I had to buy office equipment, stationery and textbooks to support my studies from home. The costs were high at a time of uncertain food and income security and also in addition to my children's study needs."

"I don't have any support so I can't get help with childcare."

"Our noho changes, and the uncertainty makes it hard to plan. I can't justify paying for childcare if I don't know if it will happen."

"COVID-19 affected my studies in terms of restrictions to go to the library and/or to access the campus to get books, resources, and support, to help with my assignments."

\section{Study space}

"I can't do any studies at home; I can't focus because everyone is at home and also all the libraries are closed as well."

"I am disappointed because there are no libraries open during COVID-19. The only way that I can write is to remove myself completely from home, but now I can't do that."

"Not able to find a quiet place to complete all assignment, such as the library due to my noisy and busy household."

\section{Face-to-face learning}

"what COVID-19 has taught me is that for me to be COVID19 free, I need to move with the times. Which also means moving from a kanohi ki te kanohi style of learning to an online space-a space that can be daunting at times."

"COVID-19 and lockdown have caused immense frustration for me because I am someone who needs the 
wānanga, kanohi-kitea, style of learning-this is how Māori learn".

"I loved the first noho, so not being able to meet together for the second noho made me feel disengage."

"Although we have our weekly class on Zoom, which is helpful, I miss the face-to-face contact with fellow students and our lecturers, Dr Benita and Dr Byron. I miss being able to bounce ideas off my classmates and the inspirational kōrero that have when we are together".

"I have found it difficult working so remotely from everyone else in the class-this makes me feel isolated."

"I have felt disengaged as a result of not being able to be with my classmates and to talk with one another and share ideas. Although we have Zoom, it is often not the same level of engagement experienced face-to-face."

One very encouraging result of the COVID-19 experience for our students has been that some of them have bonded in new ways and banded together to support one another. One student said "I think that COVID-19 has allowed some of us to bond together every week, and sometimes more than once a week, as master's colleagues. We have a tight-knit group who are willing to share and be honest in our appraisals of each other's mahi. We may not have had this without COVID-19."

\section{Commitment and quality}

Students reported that COVID-19 has caused them to have re-prioritise their lives in ways that they had not anticipated which have had negative consequences on their studies and the quality of master's work being submitted. Unfortunately, this has led to some students feeling as though they should give up on their master's studies. 
"I feel horrible and embarrassed about the poor quality of work I have handed in for my assessments. I feel like I will need to resubmit. I feel overwhelmed because I am so far behind that it feels as though I won't be able to finish mu assessments."

"I feel depressed because I don't know if I can complete my studies. I am thinking about giving up."

"In regards to my studies, I know that I can produce better quality work and so I feel huge whakama about submitting work I'm not happy with in order to meet deadlines. Even though our lecturers are super supportive, it requires a lot of processing time to shift/move through that-the experience can be exhausting."

I feel depressed about fears that I won't be able to complete my studies, and I feel like giving up."

"I have thought of quitting the master's programme because I'm drowning and not coping with things in life on my own."

"My priority is to help families who are financially struggling to keep their homes, which has meant putting my master's to the side."

"The time I would normally spend each day on my studies has been absorbed by work and whänau."

"The constant worry about the virus makes it difficult to commit, at times, to completing my assessments and studies."

"My children are unsettled; their education has fallen behind; my education has fallen behind."

"I have no time to write, and when I do, it is in the middle of the night. So I don't get enough sleep, and my writing 
doesn't make sense, then I have no time to recover and struggle to get a sense of where I am in my assignments."

\section{Staff}

As a result of the impacts of COVID-19 on the master's 2020 cohort, the master's team (the authors) have developed a range of resources to support students. These resources include two models which were published in a peer-reviewed online journal. The first model is the He Waka Hiringa Map (Rangiwai et al., 2020) (below) which was created to guide students through their two-year master's journey.

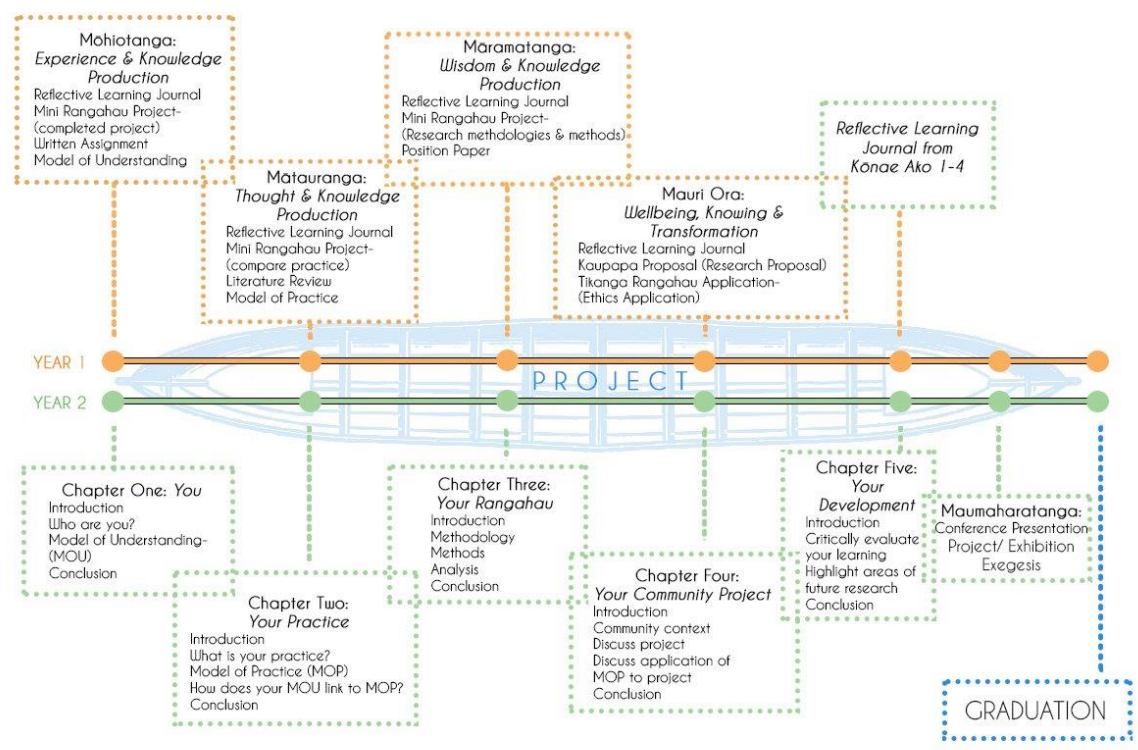

Figure 1: He Waka Hiringa Map (Rangiwai et al., 2020, p. 6) ${ }^{1}$

The second model that was developed was the Online Learning Plan (Simati-Kumar \& Rangiwai, 2020) (below). This was developed as an online teaching and learning

${ }^{1}$ Dr Benita Simati-Kumar Chand created this model. 
planning mechanism in the first instance, but also served to reassure students that their lecturers were secure in their online teaching practice.

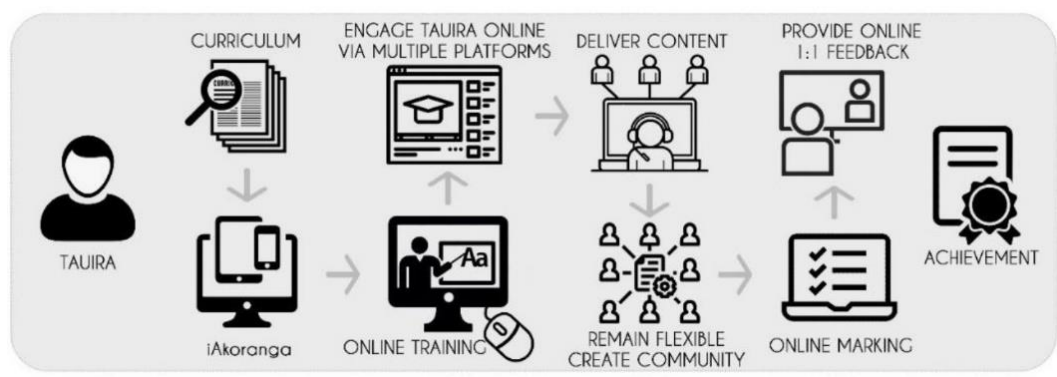

Figure 2: Online Learning Plan (Simati-Kumar \& Rangiwai, 2020, p. 8).

The master's team have also developed the following academic support resources. 


\section{Dr Benita's Academic Support Resources}

'6s Academic style: Common errors

[4 APA 7th Brief Guide

A: Paraphrasing \& Summarising

a: Paragraph structure

PE Oral presentation tips

P. How to unpack an academic reading

Reading strategies

Writing an essay 101

APA 7th Presentation

\section{Dr Byron's Academic Support Resources}

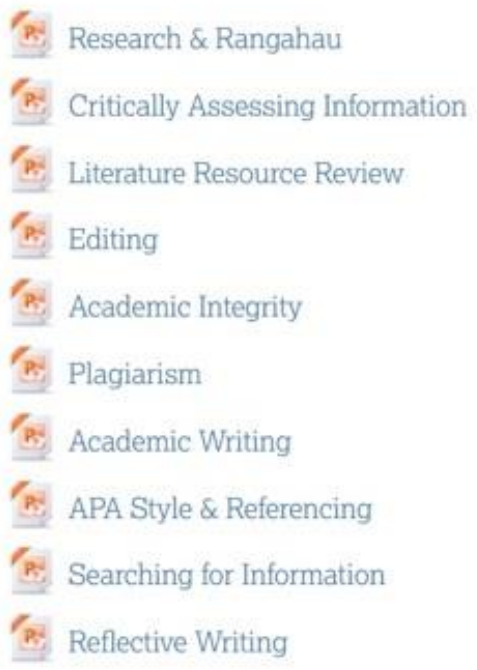

Figure 3: Dr Benita and Dr Byron's Academic Support Resources 
Our approach to teaching and learning during COVID-19 has been informed by research and has been centred entirely on the learning and academic development of our students. The 2020 master's cohort has commented about feeling supported by staff, which has been encouraging.

"I have felt well supported by my kaiako, the online learning plan developed, tutorials and workshops and one-on-ones have ensured that I have been able to complete my assignments."

"I have felt supported by my kaiako and Rosie as they have continued to be available to us when we have needed."

"I am so grateful for all the support from Dr Benita, Dr Byron and Rosie, thank you for all your support."

"My feeling is that we as tauira have been provided by our kaiako with the best resources and tools during COVID-19 to complete our assignments and stay on track during these unprecedented times."

"I am so grateful for the aroha from our kaiako and Rosie. They have gone above and beyond, and that is why I am still here today."

"Thank you for 'over-communicating' with us-it keeps us virtually connected and engaged with each other. I have personally enjoyed how you have encouraged us in knowing that many of us have doubts and distractions, but your belief that we can do this and that we are capable has motivated us to keep going."

"To be honest, I appreciate this opportunity from Dr Byron, Dr Benita and Rosie. I count my blessings, and I will not back down despite any obstacles, I will try my best 
because I will never get this great opportunity anywhere else. I truly feel a sense of belonging."

"This has been the most important work I have done in my lifetime (MAIK), a privilege I know that will transform my practice, my wairua and my whānau. The benefits are intergenerational for my own and my community. The light at the end of the tunnel alongside the manaaki from our lecturers and Rosie will get me through to the finish line."

"Though I have felt overwhelmed, anxious, and have struggled with uncertainty, I am extremely happy with the support I received from Rosie, Dr Benita Simati-Kumar and Dr Byron Rangiwai."

"I'm very grateful to have patient, persistent and compassionate kaiako who have been very supportive during this pandemic. These are unprecedented times, and I feel that our kaiako have provided a safe space to learn but also given me the push when I've needed it. Ngā tauwhirotanga a te runga rawa ki runga i a tâtou katoa."

\section{Next steps}

The master's team are continually reassessing best practice, researching for new developments concerning teaching and learning, and are engaged in further studies and professional development. Sir John Daniel (2020) argues that the COVID-19 emergency is not the time for institutions to implement complicated distance learning plans but instead that educators should be encouraged to "work with what they know" (p. 3). Our approach has been and continues to be aligned with Sir John's advice. We will work with what we know and develop our teaching and learning practice as we keep students at the centre of what we do. We assure our students, almost daily, that we are here for them, that we are flexible, and that we will support them to achieve their master's degree for themselves, and more importantly, for the families and communities they serve. 


\section{References}

Adnan, M., \& Anwar, K. (2020). Online learning amid the COVID-19 pandemic: Students' perspectives. Journal of Pedagogical Sociology and Psychology, 2(1), 45-51. https://doi.org/10.33902/JPSP.2020261309

Agarwal, S., \& Kaushik, J. S. (2020). Students' perception of online learning during COVID pandemic. The Indian Journal of Pediatrics, 87(7), 554. https://doi.org/10.1007/s12098-020-03327-7

Alawamleh, M. (2020). COVID-19 and higher education economics. Journal of Economics and Economic Education Research, 21(2), 1-2. https://searchproquestcom.ezproxy.waikato.ac.nz/docview/2424655747/ citation/AC1952C05C3148B8PQ/3?accountid=17 $\underline{287}$

Braun, V., Clarke, V., Hayfield, N. \& Terry, G. (2019). Thematic analysis. In P. Liamputtong (Ed.), Handbook of research methods in health social sciences (pp. 843-860). Springer Nature.

Burgess, S., \& Sievertsen, H. H. (2020, April 1). Schools, skills, and learning: The impact of COVID-19 on education. VoxEU. https://voxeu.org/article/impact-covid-19education

Cao, W., Fang, Z., Hou, G., Han, M., Xu, X., Dong, J., \& Zheng, J. (2020). The psychological impact of the COVID-19 epidemic on college students in China. Psychiatry Research, 287, 1-5. https://doi.org/10.1016/j.psychres.2020.112934

Crawford, J., Butler-Henderson, K., Rudolph, J., Malkawi, B., Glowatz, M., Burton, R., Magni, P. A., \& Lam, S. (2020). COVID-19: 20 countries' higher education intra-period digital pedagogy responses. Journal of Applied Learning \& Teaching, 3(1), 9-28. https://doi.org/10.37074/jalt.2020.3.1.7 
Corbera, E., Anguelovski, I., Honey-Rosés, J., \& RuizMallén, I. (2020). Academia in the time of COVID19: Towards an ethics of care. Planning Theory \& Practice, 21(2), 191-199. https://doi.org/10.1080/14649357.2020.175789 $\underline{1}$

Daniel, J. (2020). Education and the COVID-19 pandemic. Prospects, 1-6. https://doi.org/10.1007/s11125-020-09464-3

Gonzalez, T., de la Rubia, M. A., Hincz, K. P., ComasLopez, M., Subirats, L., Fort, S., \& Sacha, G. M. (2020). Influence of COVID-19 confined in students' performance in higher education. arXiv, 1-25. https://arxiv.org/abs/2004.09545

Händel, M., Stephan, M., Gläser-Zikuda, M., Kopp, B., Bedenlier, S. \& Ziegler, A. (2020). Digital readiness and its effects on higher education student socioemotional experiences in the context of COVID-19 pandemic. PsyArXiv, $1-23$. https://doi.org/10.31234/osf.io/b9pg7

Hiremath, P., Kowshik, C. S. S., Manjunath, M., \& Shettar, M. (2020). COVID-19: Impact of lockdown on mental health and tips to overcome. Asian Journal of Psychiatry, 51, 1-2. https://doi.org/j.ajp.2020.102088

Jacob, O. N., Abigeal, I., \& Lydia, A. E. (2020). Impact of COVID-19 on higher institutions development in Nigeria. Electronic Research Journal of Social Sciences and Humanities, 2(2), 126-135. http://www.eresearchjournal.com/wpcontent/uploads/2020/04/0.-Impact-ofCOVID.pdf

Kapasia, N., Paul, P., Roy, A., Saha, J., Zaveri, A., Mallick, R., Barman, B., Das, P., Chouhan, P. (2020). Impact of lockdown on learning status of undergraduate and postgraduate students during COVID-19 pandemic in West Bengal, India. Children and Youth Services Review, 116, 1-5. 
https://doi.org/10.1016/j.childyouth.2020.10519 $\underline{4}$

Krishnamurthy, S. (2020). The future of business education: A commentary in the shadow of the Covid-19 pandemic. Journal of Business Research, 117 , $1-5$. https://doi.org/10.1016.j.busres.2020.05.034 Marelli, S., Castelnuovo, A., Somma, A., Castronovo, V., Mombelli, S., Bottoni, D., Leitner, C., Fossati, A., \& Ferini-Strambi, L. (2020). Impact of COVID-19 lockdown on sleep quality in university students and administration staff. Journal of Neurology, 1-8. https://doi.org/10.1007/s00415-020-10056-6

Mogaji, E. (2020). Financial vulnerability during a pandemic: insights for Coronavirus Disease (COVID-19). Research Agenda Working Papers, 5, 57-63.

Murphy, M. P. A. (2020). COVID-19 and emergency eLearning: Consequences of the securitisation of higher education for post-pandemic pedagogy. Contemporary Security Policy, 41(3), 492-505. https://doi.org/10.1080/13523260.2020.176174 $\underline{9}$

Naciri, A., Baba, M. A., Achbani, A., \& Kharbach, A. (2020). Mobile learning in higher education: Unavoidable alternative during COVID-19. Aquademia, 4(1), 1-2. https://doi.org/10.29333/aquademia/8227

Odriozola-González., P., Planchuelo-Gómez, Á., Irurtia, M. J., \& de Luis-García, R. (2020). Psychological effects of the COVID-19 outbreak and lockdown among students and workers of a Spanish university. Psychiatry Research, 290, 1-8. https://doi.org/10.1016.j.psychres.2020.113108

Rangiwai, B., Simati-Kumar, B., \& Mataroa, R. (2020). The He Waka Hiringa Map 2020-2021: Using He Raranga Tangata to support the implementation of the He Waka Hiringa Map in the Master of Applied Indigenous Knowledge programme at Te Wānanga 
o Aotearoa in Māngere. Te Kaharoa: The eJournal on Indigenous Pacific Issues, 15(1), 1-12. https://www.tekaharoa.com/index.php/tekaharo a/article/view/294

Sahu, P. (2020). Closure of universities due to Coronavirus Disease 2019 (COVID0-19): Impact on education and mental health of students and academic staff. Cureus, 12(4), 1-6. https://doi.org/10.7759/cureus.7541

Sandars, J., Correia, R., Dankbaar, M., de Jong, P., Goh, P. S., Hege, I., Masters, K., Oh, S., Patel, R., Premkumar, K., Webb, A., \& Pusic, M. (2020). Twelve tips for rapidly migrating to online learning during the COVID-19 pandemic. MedEdPublish. https://doi.org/10.15694/mep.2020.000082.1

Simati-Kumar, B. \& Rangiwai, B. (2020). A plan for online teaching and learning for the Master of Applied Indigenous Knowledge (MAIK) programme in Māngere: Responding to COVID-19. Kaharoa: The eJournal on Indigenous Pacific Issues, 15(1), 1-14. https://www.tekaharoa.com/index.php/tekaharo a/article/view/290

Tang, W., Hu, T., Hu, B., Jin, C., Wang, G., Xie, C., Chen, S., \& Xu, J. (2020). Prevalence and correlates of PTSD and depressive symptoms one month after the outbreak of the COVID-10 epidemic in a sample of home-quarantined Chinese university students. Journal of Affective Disorders, 274, 1-7. https://doi.org/10.1016/j.jad.2020.05.009

Toquero, C. M. (2020). Challenges and opportunities for higher education amid the COVID-19 pandemic: The Philippine context. Pedagogical Research, 5(4), 1-5. https://doi.org/10.29333/pr/7947

Usak, M., Masalimova, A. R., Cherdymova, E. I., \& Shaidullina, A. R. (2020). New playmaker in science education: COVID19. Journal of Baltic Science Education, 19(2), 180-185. https://doi.org/10.33225/jbse/20.19.180 
Wang, Z., Yang, H., Yang, Y., Liu, D., Li, Z., Zhang, X., Zhang, Y., Shen, D., Chen, P., Song, W., Wang, X., Wu, X., Yang, X., \& Mao, C. (2020). Prevalence of anxiety of depression symptom, and the demands for psychological knowledge and interventions in college students during COVID-19 epidemic: A large cross-sectional study. Journal of Affective Disorders, 275, 188-193. https://doi.org/10.1016/j.jad.2020.06.034 